Monika Stańska

http://dx.doi.org/10.18778/8088-191-4.06

monika.stanska@wat.edu.pl

Ewa Walewska

ewa.walewska@wat.edu.pl

Biblioteka Główna Wojskowej Akademii Technicznej

im. Jarosława Dąbrowskiego

\title{
POLITYKA GROMADZENIA W BIBLIOTECE WOJSKOWEJ AKADEMII TECHNICZNEJ
}

\begin{abstract}
Changing reality requires also from us, librarians, a new way of perceiving the world, and, at the same time, new methods of gathering, working out and making the newly collections obtained as well as the already stored ones available. The library of the Military University of Technology in Warsaw had to find a way to fulfil the new expectations of the more and more demanding users. This process has been in progress for almost 25 years, since the times of publishing announcements, through the times of the fulfilled slips of paper and their analysis, till the times of the information published online. The university to which the described library belongs, educates mainly military students. Till 2001 they constitued one hundred per cent of the readers. Their lifestyle, the way a military student's day is organised, plus the economic, political and social conditions of the specific time period, had a fundamental influence on the acquisition policy. This paper deals with the topic of gradual changes in acquisition the coherent collections which is our current occupation. The acquisition of journals is not enclosed here, since this is attended by the workers of Journal and Digital Resources Reading Room.
\end{abstract}

Słowa kluczowe: Biblioteka Wojskowej Akademii Technicznej, gromadzenie, przemiany w bibliotece, społeczeństwo wiedzy

\section{Wstęp}

Zmieniająca się wokół rzeczywistość wymaga również od nas, bibliotekarzy, nowego sposobu postrzegania świata, a tym samym nowych metod gromadzenia, opracowania i udostępniania posiadanych czy nowo nabytych zbiorów. Oddział Gromadzenia i Opracowania Zbiorów Biblioteki Głównej Wojskowej Akademii Technicznej (BG WAT) zajmuje się gromadzeniem tylko wydawnictw zwartych. Polityką gromadzenia zbiorów czasopism zajmują się pracownicy Czytelni Czasopism i Zbiorów Elektronicznych.

Podstawowym determinantem gromadzenia książek w Bibliotece Głównej są kierunki nauczania w WAT. Określają one potrzeby użytkowników, stanowią główne kryteria i parametry uzupełniania zbiorów, tworząc pełne spektrum stanu posiadania. 


\section{Początki}

Działalność BG WAT nierozerwalnie związana jest z początkiem działalności uczelni, sięgającym $1951 \mathrm{r}$. Wtedy to w warunkach polityczno-gospodarczych jeszcze końca lat czterdziestych WAT swój kształt „oparła na wzorcu radzieckiej akademii wojskowej, wzbogacając go jednak o doświadczenia i wymogi polskiego wyższego szkolnictwa technicznego"1. Początkowo powstały cztery wydziały, dziś funkcjonuje w Akademii siedem wydziałów i jeden instytut:

1. Wydział Elektroniki (1951).

2. Wydział Mechaniczny (1959/60).

3. Wydział Nowych Technologii i Chemii (1959).

4. Wydział Cybernetyki (1968).

5. Wydział Mechatroniki i Lotnictwa (1968).

6. Wydział Inżynierii Lądowej i Geodezji (2006).

7. Wydział Logistyki (2014);

- Instytut Optoelektroniki (1994) $)^{2}$.

W pierwszym okresie istnienia Biblioteka Główna nie miała własnej siedziby. Zbiory biblioteczne mieściły się w kilku pomieszczeniach budynków należących do uczelni. W 1957 r. BG WAT doczekała się własnego lokum z obszernymi magazynami, gdzie przeniesiono wszystkie zbiory ${ }^{3}$, na które składały się:

- pozycje podarowane przez osoby prywatne, o czym przypominają ex-librisy na książkach z lat pięćdziesiątych i sześćdziesiątych lub nazwiska właścicieli na stronach tytułowych;

- $\quad$ dary innych instytucji, które zechciały podzielić się swoim stanem posiadania pozycji technicznych polsko- i obcojęzycznych;

- a także pozycje zakupione przez Dział Gromadzenia oraz instrukcje i regulaminy wydane przez Ministerstwo Brony Narodowej.

\section{Lata dziewięćdziesiąte}

Do $2001 \mathrm{r}$. WAT kształciła tylko i wyłącznie studentów mundurowych na kierunkach ściśle technicznych i wojskowych. Stanowili oni specyficzną grupę użytkowników bibliotecznych. Sposób organizacji dnia studenta wojskowego, ówczesne warunki społeczno-polityczne i gospodarcze w zasadniczy sposób wpływały na politykę gromadzenia zbiorów w Bibliotece Głównej. Żołnierze mieli ograniczoną możliwość poruszania się po Warszawie, więc i dostęp do bibliotek innych niż ich uczelniana był utrudniony. Dzień życia słuchacza (tak

\footnotetext{
${ }^{1}$ Historia WAT, [dostęp: 27.03.2015], http://www.wat.edu.pl/index.php?option=com_con tent\&view $=$ article\&id $=3 \&$ Itemid $=2$.

${ }^{2}$ Ibidem.

${ }^{3}$ A. Żądło, W. Wysokowicz, Biblioteka Gtówna Wojskowej Akademii Technicznej im. Jarostawa Dąbrowskiego 1951-1971, „Roczniki Biblioteczne” 1971, R. 15, z. 1/2, s. 403.
} 
ich wtedy nazywano) był wypełniony od rana do wieczora wykładami lub zajęciami wojskowymi, więc użytkownicy musieli mieć dostęp do niezbędnych publikacji. Literatura podstawowa na pierwsze lata nauki, z takich dziedzin jak matematyka, fizyka lub chemia gromadzona bywała w setkach, a niekiedy nawet tysiącach egzemplarzy. Do tego księgozbiór zasilano ogromnymi ilościami instrukcji i regulaminów Ministerstwa Obrony Narodowej, które były niezbędne każdemu studentowi, a przekazywane do BG WAT również $\mathrm{w}$ formie darów.

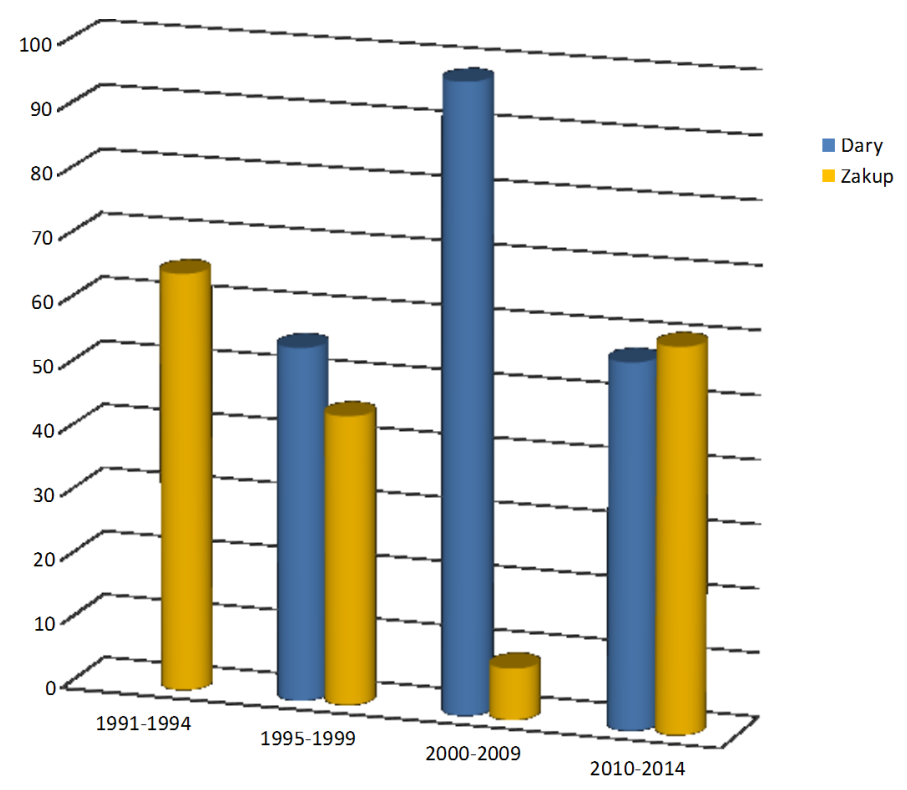

Rys. 1. Dary i zakup tytułów zagranicznych w latach 1991-2014 Źródło: książki akcesyjne za lata 1991-2014. Opracowanie własne.

Zakupów bieżących dokonywano w Głównej Księgarni Technicznej lub Głównej Księgarni Naukowej, sporadycznie w Bellonie, na podstawie składanych pisemnych zamówien, przygotowywanych w oparciu o "Zapowiedzi Wydawnicze" lub informacje zawarte w „Nowych Książkach” (cotygodniowej broszurze drukowanej z myślą o księgarzach i bibliotekarzach). Większą liczbę egzemplarzy kupowano w wydawnictwach (Wydawnictwa Naukowo Techniczne, Polskie Wydawnictwo Naukowe, Arkady, Wydawnictwa Komunikacji i Łączności) według pisemnych zamówień $\mathrm{z}$ wydziałów, wspomagając się „Planami Wydawniczymi” lub „Katalogiem Składowym” Składnicy księgarskiej. Wielkość zbiorów uzupełniano na podstawie kontaktów z użytkownikami, wykładowcami lub na podstawie analizy niezrealizowanych rewersów. Książki zagraniczne, głównie literaturę rosyjskojęzyczną, nabywano w tak 
zwanej wzorcówce ${ }^{4}$, gdzie składało się pisemne zamówienia na fiszkach i oczekiwało na transport z zagranicy. Książki anglojęzyczne (dużo rzadziej niemieckojęzyczne) kupowano za pośrednictwem przedsiębiorstwa Ars Polona lub Księgarni Panorama, poprzez pisemne zamówienia z podpisem dyrektora biblioteki. Wszystkie zakupy książek zagranicznych finansowane były z budżetu Biblioteki.

W połowie lat dziewięćdziesiątych sposób finansowania zakupów zaczął się zmieniać. Zaczęto wymagać od wydziałów większego udziału w finansowaniu zakupów zagranicznych książek naukowych, co obrazuje rys. 1. W latach 1991-1994 zakup książek zagranicznych finansowany był w całości z budżetu Biblioteki Głównej. W latach 1995-1999 Wydziały i BG WAT ponosiły koszty realizacji potrzeb zakupów tytułów zagranicznych na porównywalnym poziomie. W latach 2000-2009 Biblioteka Główna realizowała zapotrzebowania wydziałów średnio na ok. 8 tytułów rocznie, gdy w tym samym czasie liczba tytułów podarowanych przez wydział była bliska 100. Od 2010 r. BG WAT kupuje książki zagraniczne $\mathrm{z}$ własnej inicjatywy, na podstawie analizy posiadanych już tytułów i ukazujących się nowości. Ich liczba w minimalnym stopniu różni się od tych finansowanych przez wydziały.

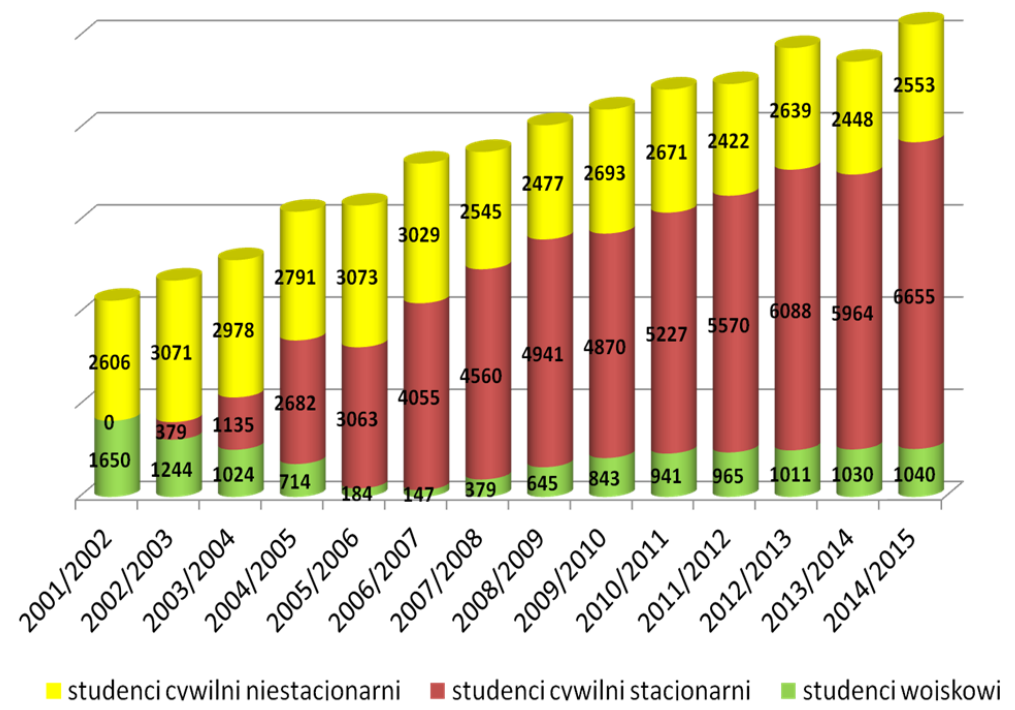

Rys. 2. Liczba studentów cywilnych i wojskowych w latach 2001-2015 Źródło: Książki akcesyjne za lata 1991-2014. Opracowanie własne.

\footnotetext{
${ }^{4}$ Księgarnia pod patronatem PAN, która mieściła się na parterze w Pałacu Kultury i Nauki.
} 


\section{Wspólczesność. Studenci}

Po pięćdziesięciu latach istnienia Akademia dokonała rewolucyjnej zmiany i wprowadziła w swoje mury studentów cywilnych, najpierw na studia zaoczne (2001 r.), a następnie od 2002 r. również na studia dzienne.

Rys. 2 przedstawia liczbę cywilnych studentów stacjonarnych, niestacjonarnych oraz wojskowych, studiujących w WAT w latach 2001-2015. Od 2001 do 2007 r. liczba studentów wojskowych maleje, natomiast w kolejnych wykazuje wyraźnie tendencje rosnące. Jednocześnie liczba studentów cywilnych przez cały prezentowany okres była niezmiennie przeważająca.

Zmiana profilu kształcenia $\mathrm{z}$ wojskowego na cywilno-wojskowy spowodowała zmiany w liczbie egzemplarzy specjalistycznych wydawnictw Ministerstwa Obrony Narodowej wpływających do BG WAT. Ilustruje to rys. 3. W latach 1991-1994 do Biblioteki Głównej wpływało rocznie średnio 3500 egzemplarzy wydawnictw specjalistycznych (w tym liczba egzemplarzy jednego tytułu wahała się od 50 do 100). Od 2000 r. liczba ta nie przekracza 200 egzemplarzy rocznie.

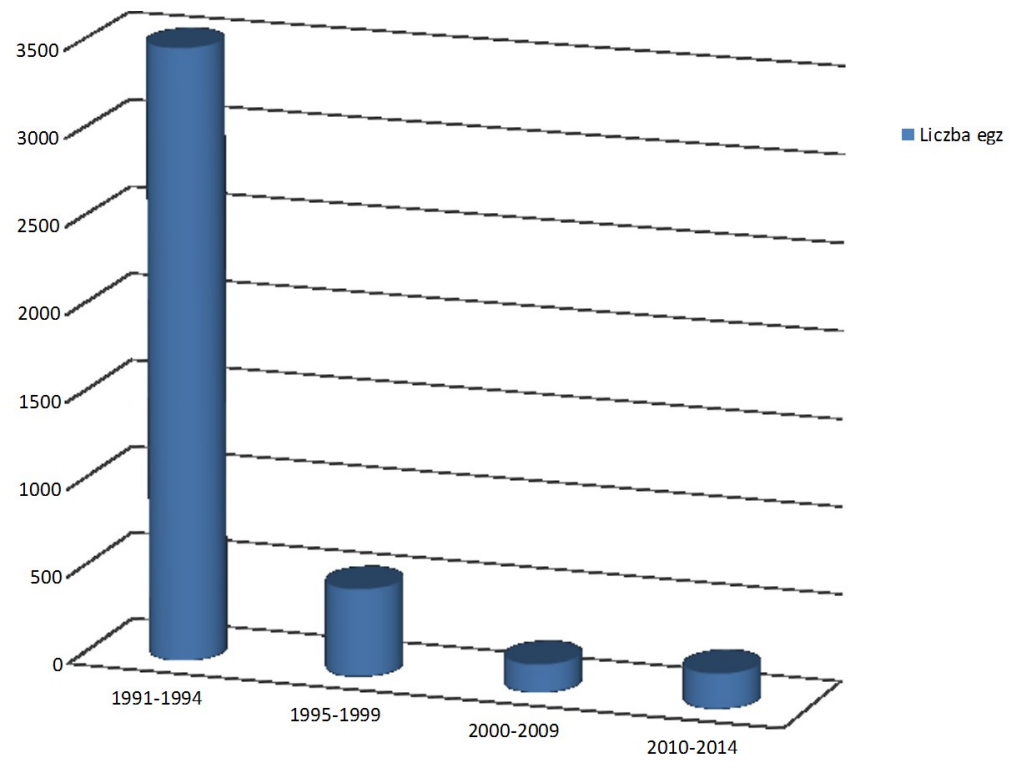

Rys. 3. Średnia roczna liczba egzemplarzy specjalistycznych wydawnictw MON Źródło: Książki akcesyjne za lata 1991-2014. Opracowanie własne. 
Wymagania, zainteresowania i potrzeby studentów wpływają zasadniczo na rozszerzenie tematyki zbiorów. Obecnie studenci studiują na 16 kierunkach:

- budownictwo;

- bezpieczeństwo narodowe;

- chemia;

- energetyka;

- $\quad$ elektronika i telekomunikacja;

- fizyka techniczna;

- geodezja i kartografia;

- $\quad$ informatyka w medycynie;

- $\quad$ inżynieria materiałowa;

- $\quad$ inżynieria bezpieczeństwa;

- $\quad$ kryptologia i cyberbezpieczeństwo;

- logistyka;

- lotnictwo i kosmonautyka;

- mechanika i budowa maszyn;

- mechatronika;

- zarządzanie.

Powstanie w 2014 r. Wydziału Logistyki ${ }^{5}$ postawiło przed Działem Gromadzenia BG WAT nowe wyzwania i zadania. Będąc samodzielną komórką Wydział tworzy indywidualne potrzeby naukowe i dydaktyczne, co mobilizuje Dział Gromadzenia do wzmożonego wysiłku w zakresie poszerzania literatury $\mathrm{z}$ tej dziedziny.

Kierunek kryptologia i cyberbezpieczeństwo ${ }^{6}$ oraz informatyka w medycynie $^{7}$, wymagają od pracowników Działu Gromadzenia skierowania zwiększonej uwagi na tę tematykę, zwłaszcza na medycynę, jako dynamicznie rozwijająca się naukę i zupełnie nową, nieznaną dyscyplinę w sferze zainteresowań BG WAT. Swoją wiedzę i doświadczenie bibliotekarze gromadzący literaturę starają się jak najpełniej wykorzystywać, aby Akademia osiągnęła wyższy poziom $\mathrm{w}$ procesie kształcenia oraz prowadzonych badaniach naukowych.

Księgozbiór Biblioteki Głównej Wojskowej Akademii Technicznej tworzony jest $\mathrm{w}$ oparciu o:

1. Znajomość kierunków studiów, badań naukowych i prac naukowobadawczych - wiedza z poszczególnych Wydziałów oraz ze stron internetowych Akademii.

\footnotetext{
${ }^{5}$ Który przekształcił się z kierunku logistyka na Wydziale Mechanicznym.

${ }^{6}$ Który kształci specjalistów na potrzeby Sił Zbrojnych, Narodowego Centrum Kryptologii oraz innych instytucji gospodarki narodowej, Kryptologia i cyberbezpieczeństwo, [dostęp 10.04. 2015], http://www.wcy.wat.edu.pl/images/stories/kw/oferta_dydaktyczna/kic.pdf.

${ }^{7}$ Gdzie studenci zdobywają wiedzę z zakresu zastosowania informatyki w obszarze projektowania, budowy i administrowania systemów komputerowych wspomagania procesów diagnostyki i terapii medycznej, zarządzania szpitalnymi zasobami medycznymi, są to nowe kierunki kształcenia na Wydziale Cybernetyki, Informatyka w medycynie, [dostęp 10.04.2015], http:// www.wcy.wat.edu.pl/images/stories/kw/oferta_dydaktyczna/iwm.pdf.
} 
2. Sugestie czytelników między innymi w ramach usługi „zaproponuj kupno książki" lub przez kontakt osobisty z czytelnikiem.

3. Przegląd sylabusów, do których dostęp mamy dzięki kontaktom z wydziałami.

4. Współpracę z pracownikami działów udostępniania, którzy mają najnowsze i najbardziej aktualne informacje o potrzebach czytelników od nich samych.

5. Analizę nowości wydawniczych:

- $\quad$ oferty wydawców i księgarzy, przedstawiane na stronach internetowych;

- $\quad$ kontakt z przedstawicielami handlowymi;

- odwiedzanie księgarń;

- udział w targach.

6. Analizę zamówień czytelniczych składanych w systemie bibliotecznym, będących cennym źródłem wiedzy o najpopularniejszych aktualnie tytułach.

Gromadzone są:

- $\quad$ książki drukowane i elektroniczne (głównie materiały konferencyjne na płytach CD);

- $\quad$ zbiory specjalne (normy, rozprawy doktorskie, których obrona odbyła się na naszej uczelni, sprawozdania z prac naukowo-badawczych).

Zastosowanie nowych technologii informatycznych w życiu Biblioteki Głównej nie tylko usprawniło pracę, ale w dzisiejszej dobie stało się koniecznością. Instytucja ma obowiązek zapewnić odbiorcom odpowiedni poziom usług, narzędzia informatyczne i dostęp do Internetu. Są to na przykład informacje o naszych nabytkach, zarówno do wypożyczalni akademickiej, jak i beletrystycznej, prezentowane na stronie Biblioteki wraz z okładkami książek.

Niemal powszechna obecnie wśród studentów umiejętność posługiwania się językiem angielskim, szeroko rozwinięta międzynarodowa wymiana studentów w ramach programów LL Erasmus, Niemiecka Centrala Wymiany Akademickiej DAAD lub MOSTECH obligują Dział Gromadzenia BG WAT do kupowania literatury w języku angielskim za pośrednictwem firm importujących i sprzedających książki naukowo-techniczne do Polski.

Do początku lat dziewięćdziesiątych księgozbiór obcojęzyczny stanowiły głównie książki w języku rosyjskim. Literatura techniczna w języku angielskim lub czasem języku niemieckim, stanowiła niewielki procent. Było to podyktowane uwarunkowaniami politycznymi panującymi w okresie komunizmu. Obecnie techniczna literatura zagraniczna gromadzona jest głównie w języku angielskim.

Postęp technologiczny spowodował, że czytelnicy oprócz tradycyjnych książek mają możliwość bezpłatnego dostępu do źródeł elektronicznych. Wśród nich znajdują się między innymi: IBUK Libra, Knovel, Aprobaty i Rekomendacje Techniczne, Polskie zasoby sieciowe z zakresu nauk technicznych - BazTOL, Directory of Open Acess Books - DOAB, Directory of Open Access Journals - DOAJ, European Mathematical Information Service - EMIS, 
Hindawi Publishing, Internetowy System Aktów Prawnych - ISAP, MIT OpenCourseWare, PubChem, Scientific Resarch. Dział Gromadzenia Biblioteki Głównej Wojskowej Akademii Technicznej ma wpływ na kształt pełnotekstowej bazy IBUK Libra, która zapewnia zaopatrzenie w literaturę, zgodnie $\mathrm{z}$ tokiem studiów lub prowadzonych badan, takich wydawnictw jak: Polskie Wydawnictwo Naukowe, Wydawnictwo Naukowo-Techniczne, Wydawnictwo Lekarskie PZWL, Wolters Kluwer Polska i inne. Pracownicy Działu Gromadzenia zajmują się wyborem tytułów do tej bazy. W chwili obecnej Biblioteka Główna zapewnia dostęp do 1018 tytułów z takich dziedzin jak nauki humanistyczne, nauki ekonomiczne, informatyka, matematyka, nauki społeczne, prawo, literatura popularnonaukowa. $\mathrm{Z}$ zasobów tych można korzystać z komputerów zarejestrowanych w sieci akademickiej lub domowych.

\section{Podsumowanie}

Ostanie 25 lat przyniosło wiele zmian w zawodzie bibliotekarza. Zdeklarowani na ogół humaniści musieli zacząć nadążać za rozwojem postępu technicznego, nowinkami technologicznymi, aby nie odstawać poziomem od czytelników, którym mają służyć pomocą.

Coraz szybsze tempo życia, niecierpliwość oraz rosnące oczekiwania użytkowników powodują powstawanie nowych systemów bibliotecznych. Usprawniają one naszą pracę, ułatwiają odbiorcom dostęp do wszelkich niezbędnych im informacji i danych, pomagają zarządzać nowocześnie zasobami bibliotecznymi, wymuszają rozwój pracowników bibliotek chcących prawidłowo funkcjonować w społeczeństwie wiedzy. Dział Gromadzenia ma przede wszystkim wpływ na to do jakiej wiedzy mają dostęp użytkownicy BG WAT. Zbiory online w znacznym stopniu poprawiają jakość usług, stają się coraz bardziej powszechną formą korzystania z zasobów BG WAT.

Jesteśmy uczestnikami zmian zachodzących we współczesnym świecie bibliotekarskim, ale jednocześnie współtwórcami tego świata.

\section{Bibliografia}

Historia WAT, [dostęp: 27.03.2015], http://www.wat.edu.pl/index.php?option=com_content\& view $=$ article $\&$ id $=3 \&$ Itemid $=2$.

Kryptologia i cyberbezpieczeństwo, [dostęp 10.04.2015], http://www.wcy.wat.edu.pl/images/ stories/kw/oferta_dydaktyczna/kic.pdf.

Książki akcesyjne Biblioteki Głównej Wojskowej Akademii Technicznej za lata 1991-2014.

Żądło A., Wysokowicz W., Biblioteka Główna Wojskowej Akademii Technicznej im. Jarosława Dąbrowskiego 1951-1971, „Roczniki Biblioteczne” 1971, R. 15, z. 1/2, s. 403-406. 